\title{
EFFECT OF ANTANAN (CENTELLA ASIATICA) AND VITAMIN C ON THE BURSA OF FABRICIUS, LIVER MALONALDEHIDE AND PERFORMANCE OF HEAT-STRESSED BROILERS
}

\author{
ENGKUS KUSNADI ${ }^{1}$, REVIANY WIDJAJAKUSUMA ${ }^{2}$, TOHA SUTARDI ${ }^{3}$, \\ PENI.S.HARDJOSWORO ${ }^{4}$ and ARIFIEN HABIBIE ${ }^{5}$ \\ 'Department of Animal Production.Faculty of Animal Husbandry, Andalas \\ University(Unand), Padang, Indonesia \\ ${ }^{2}$ Department of Physiology and Pharmacology,Faculty of Veterinary Medicine, \\ Bogor Agriculture University(IPB), Bogor, Indonesia \\ ${ }^{3}$ Department of Animal Nutrition \& Feed Science, Faculty of Animal Husbandry, \\ Bogor Agriculture Universirty(IPB), Bogor, Indonesia \\ ${ }^{4}$ Department of Animal Production, Faculty of Animal Husbandry, \\ Bogor Agriculture University (IPB), Bogor, Indonesia \\ ${ }^{1}$ Deputy Assistant for Agroindustry-Jakarta, Coordinating Ministry for Economic Affairs, \\ Jakarta, Indonesia
}

\begin{abstract}
High environmental temperatures may cause heat stress in poultry. This may increase water consumption, decrease feed consumption and in rum, decrease productivity level. In addition, high temperature contributes to oxidative stress, a condition where oxidant activity (free radicals) exceeds antioxidant activity. In our research, antanan (Centelta asiatica) and vitamin $\mathrm{C}$ were utilized as anti heat-stress agents for heat-stressed broilers. We used 120 male broilers $2-6$ weeks old, kept at $31.98 \pm 1.94{ }^{\circ} \mathrm{C}$ during the day and $27.36 \pm 1.31{ }^{\circ} \mathrm{C}$ at night. The data collected were analyzed with a completely randomized factorial design of $2 \times 3$ (2 levels of vitamin C, 3 levels of antanan at 4 replications) and continued with the contrast-orthogonal test when significantly different. The results indicate that the treatments of 5 and $10 \%$ of antanan with or without $500 \mathrm{ppm}$ of vitamin $\mathrm{C}$ and vitamin $\mathrm{C}$ alone significantly $(\mathrm{P}<0.05)$ decreased the heterophil/lymphocyte $(\mathrm{H} / \mathrm{L})$ ratio and liver malonaldchydc (MDA). These treatments, however, significantly $(\mathrm{P}<0.05)$ increased the bursa of Fabricius weight, feed consumption and body weight gain. It could be concluded that basal ration administered with $5 \%$ antanan and $500 \mathrm{ppm}$ vitamin $\mathrm{C}$ could effectively prevent broilers from heat stress. The results support the conclusion that a basal ration supplemented with $5 \%$ antanan and 500 ppm of vitamin $\mathrm{C}$ or their combinations, effectivelly reduces heat stress in broilers.
\end{abstract}

Key words : Heat stress/ Centella asiatica I Vitamin C

\section{INTRODUCTION}

High environmental temperatures may result in the accumulation of body heat load so that the body suffers from heat stress. As one of the homeothermic species, poultry could maintain their body temperature relatively constant by increasing respiration rate and water consumption and/or decreasing feed consumption. As a result, their growth rate and productivity will decrease. 
May and Lott (2001) showed that body weight gain of 3 to 7-week-old male broilers raised at a temperature of $30^{\circ} \mathrm{C}$ was $1869 \mathrm{~g}$ significantly lower than for those raised at $22^{\circ} \mathrm{C}$ with body weight gains of $2422 \mathrm{~g}$ and feed conversion decreased from 3.28 to 2.54 . The lower performances of broilers raised at high temperatures may have occurred as a result of lowered secretion of thyroid hormones (Geraert et al. 1996), decreased blood hemoglobin and hematocrit levels (Yahave/a/. 1997), or increased excretion of some minerals (Belay et al. 1992) and some amino acids (Tabiri et al. 2001).

In addition, heat stress may also cause oxidative stress in the body and develop abundant free radicals, promoting the occurrence of peroxidation of membrane lipids and hence attacking DNA and protein membranes (Rahman 2003). Takahashi and Akiba (1999) indicated that feeding oxidized lipids to broilers significantly decreased feed consumption, body weight gain, plasma vitamin $\mathrm{C}$, and plasma a-tocopherol. In fact, the results were followed by an increase in plasma malonal-dehyde (MDA) and blood heterophyl/lymphocytes $(\mathrm{H} / \mathrm{L})$ ratios as biological indices of stress in avian species.

Antanan/pegagan (Centella asiatica (L.) Urban), one of the medicinal plants containing active materials such as asiatic acid, asiaticoside, and madecasic, is readily available and evidently eliminates stress in rats (Kumar and Gupta 2003). Shukla et al. (1999) reported that placing asiaticoside on rats wound increases curability and accelerates enzymatic and nonenzymatic antioxidant activities of new-growing tissues. In addition, vitamin $\mathrm{C}$ reportedly eliminated cold stress (Sahin and Sahin 2002) and heat stress in poultry (Puthpongsiriporn et al. 2001) and showed synergism with some active materials contained in antanan (Bonte et al. 1994). With this in mind, we have examined the effect of antanan (Centella asiatica) and vitamin $\mathrm{C}$ on the bursa of Fabricius, liver malonaldehide and performance in heat-stressed broilers.

\section{MATERIALS AND METHODS}

This research used 2 to 6-week-old male broilers placed in several pens located in an open poultry house. Each pen was flitted with a 40-Watt lamp and a zinc-plate backing functioning as a heat reflector. Temperature and relative humidity measurements obtained at noon and afternoon were $31.98 \pm 1.28^{\circ} \mathrm{C}$ and $78.82 \pm 5.43 \%$, respectively. Temperature and relative humidity measurements at night and early morning were $27.36 \pm 0.88^{\circ} \mathrm{C}$ and $86.23 \pm 3.93 \%$, respectively. The levels of 500 ppm vitamin C and 10\% antanan (all plant parts) of ration used were established during preliminary trials. Vitamin $\mathrm{C}$ was dissolved in drinking water and served in the morning, two hours after the broilers received their last waterfeeding. 
One-hundred-and-twenty-two-week-old male broilers were randomly allocated into 24 pens, 5 broilers each. Antanan (5\% and 10\%) was mixed with other ingredients to make three different rations as follows: 1$)$ The control ration contained the calory as metabolizable energy (ME) $3245.02 \mathrm{kcal} / \mathrm{kg}$ and $20.84 \%$ crude protein , 2) A5 = 5\% antanan contained ME $3222.95 \mathrm{kcal} / \mathrm{kg}$ and crude protein $20.91 \%$, and 3) A10 = 10\% antanan contained ME 3202.87 $\mathrm{kcal} / \mathrm{kg}$ and crude protein $20.99 \%$. The ration formulation and nutrient composition of treatments are presented in Table 1.

Table 1. Ration formulation and nutrient composition

\begin{tabular}{|c|c|c|c|}
\hline Ingredients & A0 (\%) & A5 (\%) & $\operatorname{A10}(\%)$ \\
\hline Ground corn & 63.00 & 57.60 & 52.35 \\
\hline Soybean meal & 17.00 & 17.00 & 17.00 \\
\hline Fish meal & 11.20 & 11.20 & 11.20 \\
\hline Feather meal & 4.80 & 4.80 & 4.80 \\
\hline Antanan & 0.00 & 5.00 & 10.00 \\
\hline Coconut oil & 2.25 & 3.05 & 3.50 \\
\hline Dicalcium phosphate & 0.10 & 0.10 & 0.00 \\
\hline Calcium carbonate & 0.90 & 0.75 & 0.65 \\
\hline Premix & 0.50 & 0.50 & 0.50 \\
\hline Total & 100.00 & 100.00 & 100.00 \\
\hline \multicolumn{4}{|l|}{ Calculated nutrient content: } \\
\hline Metabolizable energy(kkal/kg) & 3245.02 & 3222.94 & 3202.87 \\
\hline Protein $(\%)$ & 20.84 & 20.91 & 20.99 \\
\hline Lipid (\%) & 6.16 & 6.15 & 6.96 \\
\hline Phosphor (\%) & 0.65 & 0.65 & 0.63 \\
\hline Calcium (\%) & 1.03 & 1.28 & 1.02 \\
\hline Crude fiber $(\%)$ & 2.46 & 3.28 & 4.09 \\
\hline Lysine (\%) & 1.39 & 1.38 & 1.36 \\
\hline Methionine (\%) & 0.51 & 0.49 & 0.48 \\
\hline Analyzed Vitamin C (mg/100 g) & 20.21 & 22.92 & 25.88 \\
\hline
\end{tabular}

$\mathrm{A} 0=0 \%$ antanan as control $(\mathrm{K}) ; \mathrm{A} 5=5 \%$ antanan and $\mathrm{A} 10=10 \%$ antanan

The broilers were subjected to six treatments, 20 broilers each, as follows:

1) $\mathrm{K}$ (Control)/ration neither contained antanan nor vitamin $\mathrm{C}$.

2) A5/ration was supplemented with $5 \%$ antanan

3) AlO/ration was supplemented with $10 \%$ antanan

4) C, drinkwater contained 500 ppm vitamin C

5) A5C, combination of A5 and C, and

6) A10C, combination of A10 and C 


\section{Variable measurements:}

1) Relative bursa of Fabricius weight taken from 4-week-old broilers, by weighing the organ and divided by body weight (Puvadolpirod and Thaxton 2000).

2) Heterophyl/lymphocyte ratio was taken from 4-week-old broilers, by hemo-cytometer method. Blood was diluted 1:101 in a red blood cell pipette with Nat and Herrick diluent. The total leucocyte count includes heterophils, lymphocytes, monocytes, basophils, and eosinophils is divided by the number of lymphocytes.

3) Liver malonaldehyde (MDA) taken from 6-week old broilers, by measuring the thiobarbituric acid (TEA) value using Tarladgis method (Apriyantono et al. 1989). Destilate from liver sample with $\mathrm{pH}$ : 1.5 , is added to the TBA reagents, covered, mixed, and incubated in boiling water bath for 35 minutes. After cooling, the absorbance of filtrate (D) was determined at $528 \mathrm{~nm}$ wave length. The TBARs values $=7.8 \mathrm{D}$ were expressed as $\mathrm{mg} / \mathrm{kg}$ of malonaldehyde per $\mathrm{kg}$ of tissue.

4) Feed consumption, body weight gain, and feed conversion are measured for 4 weeks (from 2 to 6-week-old broilers). Feed consumption was determined by weighing the given ration minus the leftover. Body weight gain was measured by weighing the final body weight at 6 weeks old minus the body weight at 2 weeks old. Feed conversion was measured by dividing feed consumption with body weight gain.

\section{Statistical analysis}

The collected data were analyzed using a completely randomized factorial design (CRD) 2 x 3 (2 levels of vitamin C i.e. 0 and 500 ppm and 3 levels of antanan i.e. 0, 5 and 10\% of rations at 4 replications), and where applicable, continued with orthogonal contrast test according to Steel and Torrie (1980).

\section{RESULTS AND DISCUSSION}

The results of the effect of antanan and vitamin $\mathrm{C}$ administration on bursa of Fabricius weight, $\mathrm{H} / \mathrm{L}$ ratio and liver MDA contents are presented in Table 2. The data for feed consumption (FC), body weight gain (BWG), and feed conversion are presented in Table 3.

From Table 2, the average relative of 4 - week bursa of Fabricius weight for controls $(\mathrm{K})$ is significantly lower than those treated with A5, A10, C, A5C, or A10C. The bursa of Fabricius weight is similar for all treatments from A5 to A10C. 
These results suggest that antanan, vitamin C, or their combinations increase burs of Fabricius weight of broilers that suffered heat stress.

The ability of antanan to stimulate lymphoid gland weight was reported i stressed rats by Sharma et al. (1996). Antanan contains phenol compounds th< potentially can prevent peroxidation of lipid membranes including $\mathrm{T}$ - and $\mathrm{E}$ lymphocyte membranes. T-lymphocytes produce cellular immunities while $\mathrm{E}$ lymphocytes produce humoral immunities produced by the bursa of Fabricius in bir species. Phenol compounds of tea extracts were potentially capable of stimulatin the production of lymphoid cells in rats (Murtini et al. 2003). On the other hanc vitamin $\mathrm{C}$ acts, as a water-soluble antioxidant capable of protecting lymphocyte from suffering heat stress (Puthpongsiriporn et al. 2001). As a result, the number o circulating lymphocytes increased so that the $\mathrm{H} / \mathrm{L}$ ratio decreased.

Table 2 shows a relationship between the increase of the bursa of Fabriciu weight and decrease in $\mathrm{H} / \mathrm{L}$ ratio because the bursa of Fabricius is a lymphoid orgai producing lymphocytes. Thus, the smaller the bursa of Fabricius size, the fewe lymphocytes will be produced, and in turn, the higher the $\mathrm{H} / \mathrm{L}$ ratio will be. Increase of the relative lymphoid organ weight occurred as a result of antanan feeding whicl was demonstrated by Sharma et al. (1996), while increase of the relative bursa o Fabricius weight as a result of supplementing vitamin $\mathrm{C}$ to broilers was reported b] Anim et al. (2000).

Table 2. Effects of the administration of antanan and vitamin $\mathrm{C}$ on the weight of bursa of Fabricius, H/L ratio and liver MDA levels of male broilers 2 to 6 weeks old.

\begin{tabular}{lcccccc}
\hline \hline & \multicolumn{5}{c}{ Treatments } \\
\cline { 2 - 6 } Variables & $\mathrm{K}$ & $\mathrm{A} 5$ & $\mathrm{~A} 10$ & $\mathrm{C}$ & A5C & A10C \\
\cline { 2 - 6 } & $1.45 \pm 0.63^{\mathrm{a}}$ & $2.89 \pm 0.85^{\mathrm{b}}$ & $2.80 \pm 0.29^{\mathrm{b}}$ & $2.38 \pm 0.73^{\mathrm{b}}$ & $2.73 \pm 1.08^{\mathrm{b}}$ & $2.88 \pm 0.32^{\mathrm{b}}$ \\
$\begin{array}{l}\text { Bursa of } \\
\text { Fabricius }(\mathrm{g} / \mathrm{kg}\end{array}$ & & & & & \\
$\begin{array}{l}\text { BW) } \\
\mathrm{H} / \mathrm{L} \text { ratio }\end{array}$ & $0.93 \pm 0.41^{\mathrm{b}}$ & $0.49 \pm 0.20^{\mathrm{a}}$ & $0.39 \pm 0.16^{\mathrm{a}}$ & $0.79 \pm 0.41^{\mathrm{a}}$ & $0.46 \pm 0.34^{\mathrm{a}}$ & $0.43 \pm 0.11^{\mathrm{a}}$ \\
$\begin{array}{l}\text { MDA } \\
(\mathrm{mg} / \mathrm{l} 00 \mathrm{~g})\end{array}$ & $15.09 \pm 4.00^{\mathrm{d}}$ & $14.16 \pm 4.70^{\mathrm{c}}$ & $6.40 \pm 2.9^{\mathrm{b}}$ & $2.79 \pm 1.04^{\mathrm{a}}$ & $9.96 \pm 8.17^{\mathrm{b}}$ & $8.46 \pm 6.54^{\mathrm{b}}$ \\
\hline
\end{tabular}

${ }^{\mathrm{a}-\mathrm{d}}$ Means $\pm \mathrm{SE}$ in a row with no common supercript differ significantly $(\mathrm{P}<0.05)$ $\mathrm{K}=$ control; $\mathrm{A} 5=5 \%$ antanan; $\mathrm{A} 10=10 \%$ antanan; $\mathrm{C}=500 \mathrm{ppm}$ vitamin $\mathrm{C} ; \mathrm{A} 5 \mathrm{C}=5 \%$ antanan + $500 \mathrm{ppm}$ vitamin $\mathrm{C}$ and $\mathrm{A} 10 \mathrm{C}=10 \%$ antanan $+500 \mathrm{ppm}$ vitamin $\mathrm{C}$

Heat stress generating oxidative stress may increase MDA content as a result of lipid peroxidation, especially for unsaturated fatty acids of membrane cells. Feeding 
antioxidants, i.e. antanan and vitamin C, significantly decreases liver MDA content. Besides of being able to relieve free radicals by releasing an electron and a proton (a hydrogen ion), phenol compounds are also able to provide a chelating effect in such a way that phenols bind to transition ions. Unbound metals might increase free radicals (Pietta 2000). In addition, phenol compounds are characterized by flavonoids that are able to decrease fluidity of cell membranes so that it may decrease diffusion of free radicals and MDA contents. This is also true for vitamin $\mathrm{C}$, a water-soluble antioxidant with 2 hydroxyl groups at $€ 2$ and $€ 3$ that are readily oxidized (Sediaoetama 1987).

Table 3. Effects of the administration of antanan and vitamin $\mathrm{C}$ on feed consumption (FC), body weight gain (BWG), and feed conversion (FC/BWG)

\begin{tabular}{lcccccc}
\hline \hline \multirow{2}{*}{ Variables } & \multicolumn{5}{c}{ Treatments } \\
\cline { 2 - 7 } & K & A5 & A10 & C & A5C & A10C \\
\hline FC (g) & $2711 \pm 196^{\mathrm{a}}$ & $3026 \pm 229^{\mathrm{b}}$ & $3071 \pm 14^{\mathrm{b}}$ & $2883 \pm 36^{\mathrm{b}}$ & $3156 \pm 247^{\mathrm{b}}$ & $2935 \pm 198^{\mathrm{b}}$ \\
BWG (g) & $1181 \pm 66^{\mathrm{a}}$ & $1297 \pm 113^{\mathrm{b}}$ & $1347 \pm 11^{\mathrm{b}}$ & $1254 \pm 35^{\mathrm{b}}$ & $1376 \pm 135^{\mathrm{b}}$ & $1330 \pm 100^{\mathrm{b}}$ \\
Feed conversion & $2.30 \pm 0.16^{\mathrm{a}}$ & $2.35 \pm 0.31^{\mathrm{a}}$ & $2.42 \pm 0.30^{\mathrm{a}}$ & $2.30 \pm 0.23^{\mathrm{a}}$ & $2.31 \pm 0.32^{\mathrm{a}}$ & $2.22 \pm 0.29^{\mathrm{a}}$ \\
\hline
\end{tabular}

${ }^{a-b}$ Means $\pm S E$ in a row with no common supercript differ significantly $(\mathrm{P}<0.05)$

$\mathrm{K}=$ control; $\mathrm{A} 5=5 \%$ antanan; $\mathrm{Al} 10=10 \%$ antanan; $\mathrm{C}=500 \mathrm{ppm}$ vitamin $\mathrm{C} ; \mathrm{A} 5 \mathrm{C}=5 \%$ antanan + $500 \mathrm{ppm}$ vitamin $\mathrm{C}$ and $\mathrm{A} 10 \mathrm{C}=10 \%$ antanan $+500 \mathrm{ppm}$ vitamin $\mathrm{C}$

In addition, it is unmistakable that feeding antanan and vitamin $\mathrm{C}$ increases feed consumption and body weight gain of broilers over four weeks (2-6 weeks of age) but not for feed conversion (Table 3). This agrees with the reports of Anim et al. 2000) for broilers and Sharma and Sharma (2002) for rats suffering from stress. Antanan contains antioxidants such as phenol compounds that are capable of eliminating oxidative stress processes (Blokhina 2000), as is apparent from the decrease of $\mathrm{H} / \mathrm{L}$ ratios, liver MDA levels and increase of bursa of Fabricius weights reported here.

\section{CONCLUSIONS}

Feeding antanan or vitamin $\mathrm{C}$ or the combination of antanan and vitamin $\mathrm{C}$ increases bursa of Fabricius weight, feed consumption, and body weight gain but decreases $\mathrm{H} / \mathrm{L}$ ratio and liver MDA levels. The combination of $5 \%$ antanan and 
vitamin $\mathrm{C}$ tends to increase feed consumption and body weight gain and, therefore this treatment tends to be very effective in alleviating heat stress in broilers.

\section{ACKNOWLEDGEMENTS}

The authors wish to thank the Department of Higher Education, Nations Department of Education, Republic of Indonesia and SEAMEO - SEARCA Regional Center for Graduate Study and Research in Agriculture, College, Lagun 4031 Philippines for their financial support.

\section{REFERENCES}

Anim AJ, TL. Lin, PY. Hester, D. Thiagarajan, BA. Watkins and CC. Wu. 2000. Ascorbic aci supplementation improved antibody response to infectious bursal disease vaccination in chickens Poultry Sci. 79: 680-688.

Apryantono.A, D.Fardiaz, NL.Puspitasari, Scdarnawati and S.Budiyanto. 1989. Analisis Pangar Departcmen Pcndidikan dan Kcbudayaan Dircktorat Jcnderal Pcndidikan Tinggi Pusat Anta Universitas Pangan dan Gizi Institut Pcrtanian Bogor.

Belay T, Wicmusz CJ and RG. Teeter. 1992. Mineral balance and urinary and fecal mineral excrctioi profile of broilers housed in thcrmoncutral and heat-distressed environments. Poultry Sci. 71: 104 - 1047.

Blokhina O. 2000. Anoxia and oxidativc stress: Lipid pcroxidation, mitochondria! functions in plant antioxidant status and mitochondria! functions in plants http://ethesis.helsinki.fi/iulkaisut/mat/bioti/vk/blokhina/anoxiaan.html. [20 Dcscmbcr 2003].

Bonte F, Dumas M, Chaudagnc C and A. Mcybcck. 1994. Influence of asiatic acid, madccassic acid, am asiaticoside on human collagen I synthesis. Planta Med. 60: 133 - 135.

Geraert PA, Padilha JCF and S. Guillaumin 1996. Metabolic and endocrine changes by chronic hca exposure in broiler chickens: biological and endocrinological variables. Br. J. Nutr.75:205-216.

Gross WB and HS. Siegel. 1983. Evaluation of the Heterophil/Lymphocyte Ratio as a Measure of Stres in Chickens. Avian Dieseasc.27: 972 - 979.

Kumar VMH and YK. Gupta. 2003. Effect of Centella asiatica on cognition and oxidative stress in ai intracerebroventricular streptozotocin model of Alzheimers disease in rat. Clin Exp Pharmaco Physiol 30: 336342.

May JD and BD. Lott. 2001. Relating weight gain and feed:gain of male and female broilers to rearini temperature. Poultry Sci 80: 581-58444.

Murtini S, Murwani R, Bunawan A, Handharyani E and F. Satrija. 2003. Effects of inoculation route am dose level of tea mistletoe (Scurrula oortiana) stem extract on the development of lymphoi< follicle of bursa fabricius in chick embryonated eggs. International Symposium on Biomedicincs $18^{\text {lh }}$ and $19^{\text {th }}$ September 2003. IPB. 
Pietta PG. 2000. Flavonoids as antioxidants. Reviews. J Nat Prod 63: 1035-1042.

Puthpongsiriporn U, Scheidelcr SE, Sell JL and MM. Beck. 2001. Effects of vitamin E and C supplementation on performance, in vitro lymphocyte proliferation, and antioxidant status of laying hens during heat stress. Poultry Sci 80: 1190-1200.

Puvadolpirod S and JP. Thaxton. 2000. Model of physiological stress in chickens 1. Response Parameters. Poultry Sci 79: 363-369.

Rahman.I. 2003. Oxidative stress, chromatin remodelling and gene transciption in inflammation and chronic lung desease. J.Biochcm. Mol. Biol. 36: 95-109.

Sahin K and N. Sahin. 2002. Efcct of chromium picolinatc and ascorbic acid dietary supplementation on nitrogen and mineral excretion of laying hens reared in low ambient temperature $\left(7^{\circ} \mathrm{C}\right)$. Acta Vet Brno 71 : 183-189.

Sediaoetama, AD. 1987. Vitaminologi. Jakarta: Balai Pustaka.

Sharma DNK, Khosa RL, Chansouria JPN and N. Saha. 1996. Antistrcss activity of Tinospora cordifolia and Centella asiatica extracts. Phytotherapy-Rescarch 10: 181 - 183.

Sharma J and R. Sharma. 2002. Radioprotcction of Swiss albino mouse by Centella asiatica extract. Phytotherapy-Research 16: 785 - 786.

Shukla A, Rasik AM, and BN. Dhawan. 1999. Asiaticoside-induced elevation of antioxidant levels in healing wounds. Phytotherapy-Research 13: 50-54.

Steel ROD and JH. Torrie. 1980. Principles and procedures of statistic, second ed, Graw-Hall, Book Comp, New York.

Tabiri HY, Sato K, Takahashi K, Toyomizu M, and Y. Akiba. 2000. Effects of acute heat stress on plasma amino acids concentration of broiler chickens. Jpn Poult Sci 37: 86-94.

Takahashi K and Y. Akiba. 1999. Effect of oxidized fat on performance and some physiological responses in broiler chickens. J Poult Sci 36: 304-310.

Yahav S, Straschnow A, Plavnik I and S. Hurwitz 1997. Blood system response of chickens to changes in environmental temperature. Poultry Sci 76: 627 - 633. 